\title{
The suitability assessment of the tree species in the urban parks and urban forest in Kediri City, East Java, Indonesia
}

\author{
WHISNU FEBRY AFRIANTO ${ }^{1, \boldsymbol{}}$, , SUSANTI INDRIYA WATI ${ }^{2}$, TAUFIQ HIDAYATULLAH ${ }^{3}$ \\ ${ }^{1}$ Ecosystem and Biodiversity (Ecosbio). Jl. Merapi 02/01, Datengan, Grogol, Kediri 64151, East Java, Indonesia, `email: whisnu.afrianto@apps.ipb.ac.id \\ ${ }^{2}$ Politeknik Pembangunan Pertanian Manokwari. Jl. SPMA Reremi, Manokwari 98312, West Papua, Indonesia \\ ${ }^{3}$ Politeknik Pembangunan Pertanian Medan. Jl. Binjai Km. 10, Deli Serdang 20351, North Sumatra, Indonesia
}

Manuscript received: 20 January 2021. Revision accepted: 29 June 2021.

\begin{abstract}
Afrianto WF, Wati SI, Hidayatullah T. 2021. The suitability assessment of the tree species in the urban parks and urban forest in Kediri City, East Java, Indonesia. Nusantara Bioscience 13: 131-139. Kediri has several urban parks and an urban forest as green open space (GOS), which have essential roles in economical, social, aesthetical, and ecological aspects. Generally, urban trees provide ecosystem services, such as carbon sequestration, stormwater attenuation, energy conservation, habitat for wildlife, and air, water, and noise pollutants reduction. The present study aimed to (i) determine tree diversity in five urban parks and an urban forest in Kediri City and (ii) evaluate the suitability of tree species based on three indicators (silviculture, management, and aesthetic). This study was conducted in five urban parks and one urban forest in Kediri City. The suitability assessment was carried out through a literature review. The results showed that 29 tree species belonging to 17 families were found in the study sites, with the family Fabaceae being the most dominant one with five species. The number of exotic tree species (17) was higher than that of the native ones (12). The suitability assessment results showed that 21 tree species had a high score of 39-44, and only eight urban tree species had a medium score of 36-38. The urban parks and forests in Kediri were managed to conserve germplasm, recreation, and protection. Therefore, the shapes had to be clumped and lined. This study will contribute information to be used as guidance for urban tree management and policy framework.
\end{abstract}

Keywords: Suitability assessment, tree species, urban forest, urban parks

\section{INTRODUCTION}

Kediri is a city in East Java Province, Indonesia. The Kediri's by law (PERDA) No. 1 of 2012 states that the provision of total green open spaces (GOS) is approximately 1.268 ha or only $20 \%$ of the entire area. The Spatial Planning Law No 26, the year 2007, stipulates that the minimum GOS should be $30 \%$ (20\% public and $10 \%$ private) of the total city area. Thus, Kediri City needs around $10 \%$ to reach the standard for minimum GOS area. The total GOS needed in an area can be measured by three variables, (i) population, (ii) location, and (iii) oxygen requirement (Ardani et al. 2013). For instance, according to the Minister of Public Works Number: 05/PRT/M /2008, the GOS needed should be based on the population, namely $20 \mathrm{~m}^{2}$ /individual (Fitri et al. 2020). In Kediri City, the GOS consists of urban parks and an urban forest. The GOS in Kediri is used by communities and the government for economic and social activities, such as a place for mobile libraries (Ningtyas 2019). Kediri's GOS is considered good based on the key performance indexes (ecological, economical, aesthetical, and social aspects) (Paulina and Murtedjo 2018).

Urban trees have essential roles such as economic, public health, visual, and aesthetic (Roy et al. 2012). In terms of ecosystem services, they are necessary for carbon sequestration, stormwater attenuation, energy conservation, habitat for wildlife, and reducing air, water, and noise pollutants (Hirokawa 2011; Roy et al. 2012; Roeland et al.
2019). High plant diversity in urban areas can be a bridge for humans to experience nature and wildlife (Jasmani et al. 2015). The urban trees also contribute to two points of Sustainable Development Goals (SDGs), which are 15 (life on land) and 17 (partnerships for the goals) goals (Turner-Skoff and Cavender 2019).

Besides the total areas of GOS, urban tree species selection is an essential aspect of urban green area management. The urban tree species should be selected according to growing requirements so the planted trees can grow and function optimally (Mukhlison 2013). Furthermore, the standard of urban tree selection can be used to optimize the infrastructure development benefits (Núñez-Florez et al. 2019). Moreover, urban trees should generally tolerate environmental stress and meet silviculture, management, and aesthetic indicators (Sæbø et al. 2005). Urban parks and an urban forest in Kediri refer to urban green spaces with an area smaller than 4 hectares. Because of the limited area, the tree species diversity in the urban areas of Kediri City is low. This phenomenon will be a challenge for management because the diversity of tree species determines the resilience of urban parks and forests (Sjöman et al. 2012; Sjöman et. 2018). Therefore, this study aimed to (i) determine the tree diversity in urban parks and an urban forest of Kediri City and (ii) evaluate the suitability of tree species based on three indicators (silviculture, management, and aesthetic). This study will contribute information to be used as a management and policy framework for urban areas. 


\section{MATERIALS AND METHODS}

\section{Study area}

This research was conducted by analyzing the tree species in five urban parks and an urban forest of Kediri City (coordinates $7^{\circ} 48^{\prime} 59.8^{\prime \prime} \mathrm{S} 112^{\circ} 0^{\prime} 42.9^{\prime \prime} \mathrm{E}$ ), East Java, Indonesia (Figure 1). The total area of Kediri City is 63.40 $\mathrm{km}^{2}$ divided into three sub-districts: Mojoroto, Kota, and Pesantren Sub-Districts. The location sampling sites there were (i) Kediri Square, (ii) Ngronggo Park, (iii) Sekartaji Park, (iv) Harmoni Park, (v) Kediri Memorial Park, and (vi) Joyoboyo Urban Forest. Those locations were chosen because these study sites are the existing GOS in Kediri (Sulistiyowati and Yuantika 2019).

\section{Data collection}

The data were collected with a rapid assessment of the field and a literature review from the previous researchers (Sulistiyowati and Yuantika 2019). The tree identified in the study sites were those with a diameter at breast height (DBH) of $>10 \mathrm{~cm}$ and a height of $>1.5 \mathrm{~m}$. The tree species were divided into two categories: (i) native species, i.e., the species naturally distributed in Indonesia, and (ii) exotic species, i.e., those naturally distributed outside Indonesia.

\section{Data analysis}

The score of suitability was examined with the literature review analysis. The suitability of the tree species was analyzed through data processing, tabulation, and descriptive study. The class interval was determined through a formula from the highest score to the lowest score/total of classes. Components of evaluation to calculate the score of urban parks and urban forest vegetation were shown in Table 1 (Sæbø et al. 2005; Indriyanto 2006; Mukhlison 2013). Literature review through journals, the website CABI (www.cabi.org), and other scientific documents were used to examine all criteria assessment of the tree species. The suitability level was determined by calculating the score of all urban tree species found. The score was divided into three suitability levels, i.e. (i) Low (score 23-30), (ii) Medium (score 3138), and (iii) High (score 39-46).
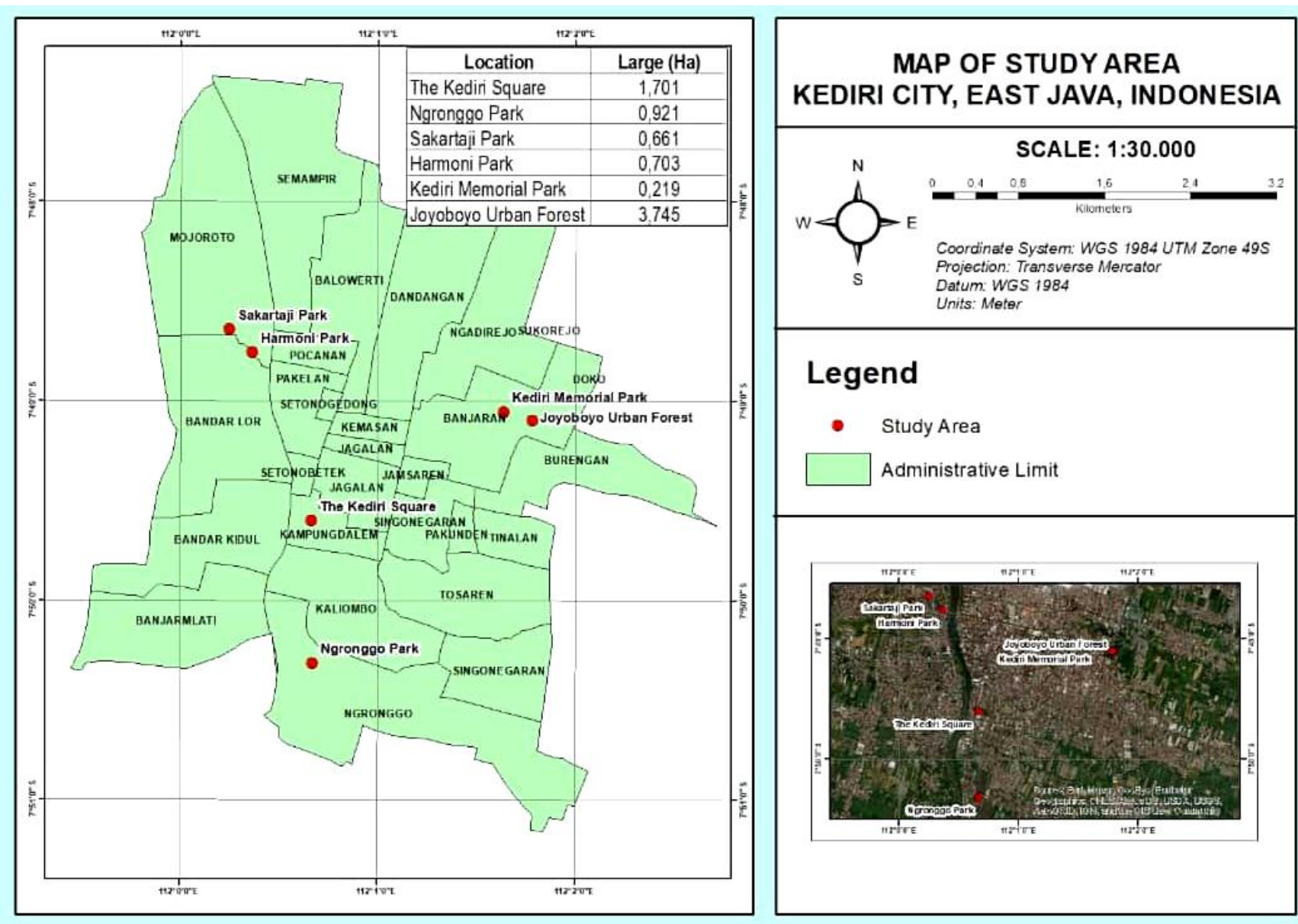

Figure 1. The map of the sites of urban parks and an urban forest of Kediri City, East Java, Indonesia, i.e., The Kediri Square, Ngronggo Park, Sekartaji Park, Harmoni Park, Kediri Memorial Park, and Joyoboyo Urban Forest 
Table 1. Suitability assessment indicators, components, criteria, and the score of urban tree species

\begin{tabular}{|c|c|c|c|}
\hline Indicators & Components & Criteria & Description \\
\hline \multirow[t]{11}{*}{ Silviculture } & Elevation & $\begin{array}{l}0-200 \mathrm{~m} \text { asl } \\
>500 \mathrm{~m} \text { asl }\end{array}$ & Most of Kediri's areas are at $63-100 \mathrm{~m}$ asl. \\
\hline & Rainfall & $\begin{array}{l}1,000-2,021 \mathrm{~mm} / \text { year } \\
<1,000 \text { and }>2021 \mathrm{~mm} / \text { year }\end{array}$ & Kediri has a rainfall of $1000-2021 \mathrm{~mm} /$ year. \\
\hline & $\begin{array}{l}\text { Nutrient-poor soil } \\
\text { tolerance }\end{array}$ & $\begin{array}{l}\text { Tolerant } \\
\text { Not tolerant }\end{array}$ & $\begin{array}{l}\text { Generally, trees can become more adaptive in soil } \\
\text { conditions. Still, urban areas probably have much more } \\
\text { significant differences in soil substrates than what can be } \\
\text { assumed through a tree plantation program }\end{array}$ \\
\hline & Restoration of soil fertility & $\begin{array}{l}\text { Possible } \\
\text { Not possible }\end{array}$ & $\begin{array}{l}\text { Urban areas probably have much more significant } \\
\text { differences in soil substrates. Thus it is important to } \\
\text { select urban trees that can restore soil conditions. }\end{array}$ \\
\hline & $\begin{array}{l}\text { Pests and diseases } \\
\text { resistance }\end{array}$ & $\begin{array}{l}\text { Resistant } \\
\text { Not resistant }\end{array}$ & Tree pests and diseases may cause death to trees. \\
\hline & Shed leaves & $\begin{array}{l}\text { Evergreen } \\
\text { Deciduous }\end{array}$ & $\begin{array}{l}\text { An evergreen canopy can provide shade and produce } \\
\text { oxygen. }\end{array}$ \\
\hline & $\begin{array}{l}\text { Stem and branch resistance } \\
\text { from wind }\end{array}$ & $\begin{array}{l}\text { Not easy to fall and break } \\
\text { Easy to fall and break }\end{array}$ & $\begin{array}{l}\text { Death and severe damage may result from falling trees } \\
\text { and branches. }\end{array}$ \\
\hline & $\begin{array}{l}\text { Root condition of the } \\
\text { surrounding buildings }\end{array}$ & $\begin{array}{l}\text { Not destroying/disturbing } \\
\text { Destroying/disturbing }\end{array}$ & $\begin{array}{l}\text { Roots may damage pavements and cause mishaps to } \\
\text { people. }\end{array}$ \\
\hline & High-temperature tolerance & $\begin{array}{l}\text { Tolerant } \\
\text { Not tolerant }\end{array}$ & $\begin{array}{l}\text { Climate change increases temperature gradually, which } \\
\text { impacts the phenology of trees. }\end{array}$ \\
\hline & Light tolerance & Tolerant & Trees planted around the tall building areas may endure \\
\hline & Water stress tolerance & $\begin{array}{l}\text { Not tolerant } \\
\text { Tolerant } \\
\text { Not tolerant }\end{array}$ & $\begin{array}{l}\text { low light levels for part of the day/year. } \\
\text { Water stress is primarily intervened through working the } \\
\text { stomatal gap of the trees (water use effectiveness). }\end{array}$ \\
\hline \multirow[t]{7}{*}{ Management } & Planting method & $\begin{array}{l}\text { Easy } \\
\text { Difficult }\end{array}$ & East to plant trees may reduce budget and efforts. \\
\hline & Maintaining Method & $\begin{array}{l}\text { Easy and cheap } \\
\text { Difficult and expensive }\end{array}$ & Easy-maintaining trees may reduce budget and effort. \\
\hline & Security Method & $\begin{array}{l}\text { Easy } \\
\text { Difficult }\end{array}$ & $\begin{array}{l}\text { When trees grow bigger, they can cause potential } \\
\text { damage to public safety. }\end{array}$ \\
\hline & Utilization method & $\begin{array}{l}\text { Easy } \\
\text { Difficult }\end{array}$ & $\begin{array}{l}\text { The utilization should be done according to the functions } \\
\text { and objectives of urban forest establishment. }\end{array}$ \\
\hline & $\begin{array}{l}\text { The function of the canopy } \\
\text { as a shade (thick and tight) }\end{array}$ & $\begin{array}{l}\text { Good } \\
\text { Not good }\end{array}$ & Thick and tight canopy provide shade. \\
\hline & $\begin{array}{l}\text { The function of the canopy } \\
\text { as wind protection (strong } \\
\text { and tight) }\end{array}$ & $\begin{array}{l}\text { Good } \\
\text { Not good }\end{array}$ & A strong and tight canopy protects against wind. \\
\hline & Ability to reduce pollution & $\begin{array}{l}\text { High } \\
\text { Low }\end{array}$ & $\begin{array}{l}\text { Emissions from vehicles and industry are high in urban } \\
\text { areas. }\end{array}$ \\
\hline \multirow[t]{5}{*}{ Aesthetic } & $\begin{array}{l}\text { Habit (canopy, branching, } \\
\text { leaf and/or flower) }\end{array}$ & $\begin{array}{l}\text { Beautiful } \\
\text { Not Beautiful }\end{array}$ & $\begin{array}{l}\text { Beautiful trees can increase the aesthetic value of the } \\
\text { urban environment. However, the judgment is subjective } \\
\text { because these attributes allude to aesthetic aspects such } \\
\text { as the crown space, color, flowers, odor of the leaves, } \\
\text { and fruits. }\end{array}$ \\
\hline & Function for education & $\begin{array}{l}\text { Yes } \\
\text { No }\end{array}$ & Trees can be used for educational purposes. \\
\hline & Fruit size & $\begin{array}{l}\text { Small } \\
\text { Big }\end{array}$ & $\begin{array}{l}\text { Large fruit may potentially cause damage to people at } \\
\text { the sites. }\end{array}$ \\
\hline & Toxic/dangerous sap & $\begin{array}{l}\text { No } \\
\text { Yes }\end{array}$ & $\begin{array}{l}\text { Toxic sap may potentially cause damage to people at the } \\
\text { sites. }\end{array}$ \\
\hline & $\begin{array}{l}\text { Potential allergies from } \\
\text { pollen }\end{array}$ & $\begin{array}{l}\text { No } \\
\text { Yes }\end{array}$ & $\begin{array}{l}\text { Pollen may potentially cause damage to some people } \\
\text { that are allergic to pollen at the sites. }\end{array}$ \\
\hline
\end{tabular}




\section{RESULTS AND DISCUSSION}

\section{The tree species diversity in urban parks and an urban forest of Kediri City}

According to Government Regulation Number 63 of 2002 regarding Urban Forests, the urban parks and urban forests in Kediri were established to conserve germplasm, recreation, and protection, and the shapes were clumped and lined (Figure 2). Twenty-nine tree species belonging to 17 families were recorded in this study (Table 2) (Sulistiyowati and Yuantika 2019). Urban Forest of Joyoboyo had the richest tree species diversity with 15 species. On the other hand, Harmoni Park had only three tree species, the lowest tree species diversity. The tree species diversity is affected by the area of the parks or forest. Urban Forest Joyoboyo has the largest area, i.e., 3.745 Ha. Beringin ( $F$. benjamina) and glodokan tiang $(P$. longifolia) were tree species most frequently found in the six study sites. Fabaceae had the most tree species (five species), followed by Arecaceae (four species). According to Mukhlison (2013), Fabaceae was also prevalent in 10 urban forests of Yogyakarta City. However, species from the family Fabaceae were not found in urban forests in the same province, Trenggalek District (Amianti et al. 2019).

Knowing natural distribution is essential to prevent the potential damage of invasive species in the ecosystem (Vogt et al. 2017). In this study, the number of exotic tree species (17 or $58.62 \%$ ) was higher than that of the native ones (12 or $41.38 \%$ ). More exotic species were also found in roadside trees in five cities of Sumatra (Wiryono et al. 2018). The presence of exotic species may result in a negative impact on the native species in urban green spaces, such as the risk for animal-plant interaction, escalate the negative impact of biological invasion, threaten biodiversity preservation, and reduce the reproductive success of indigenous tree species (e Silva et al. 2020). However, according to Sjöman et al. (2018), native tree species might be too restricted to provide ecosystem services and resilience in challenging urban circumstances based on the investigation in Central and Northern Europe. Exotic and native species have advantages and disadvantages. For instance, exotic tree species promote lower arthropod communities than native tree species but may also be more resistant to herbivorous pests (Frank et al. 2019).

One endangered tree species found in the Kediri Square and Joyoboyo Urban Forest was Angsana (P. indicus). Even though this is classified as an endangered species, it can still be found as an urban tree in Indonesia (Julianty et al. 2015). 11 species (37.93\%) were found as the least concern (LC) based on IUCN status. On the other hand, Mahoni (S. mahogany), located in Kediri Memorial Park, and the Urban Forest of Joyoboyo were classified as near threatened (NT). Moreover, mangga (M. indica) in the Urban Forest of Joyoboyo was classified as data deficient (DD).

\section{The tree species suitability in urban parks and an urban forest of Kediri City}

The result of the suitability assessment showed that 21 urban tree species had a high level of suitability, and only eight urban tree species had a medium level (Table 3). Cemara angin (C. equisetifolia) and trembesi (A. saman) had the highest score, i.e., 44. On the other hand, sirsak ( $A$. muricata) and blimbing (A. carambola) had the lowest score, namely 36 . Therefore, most medium-level tree species were found in the Urban Forest of Joyoboyo.
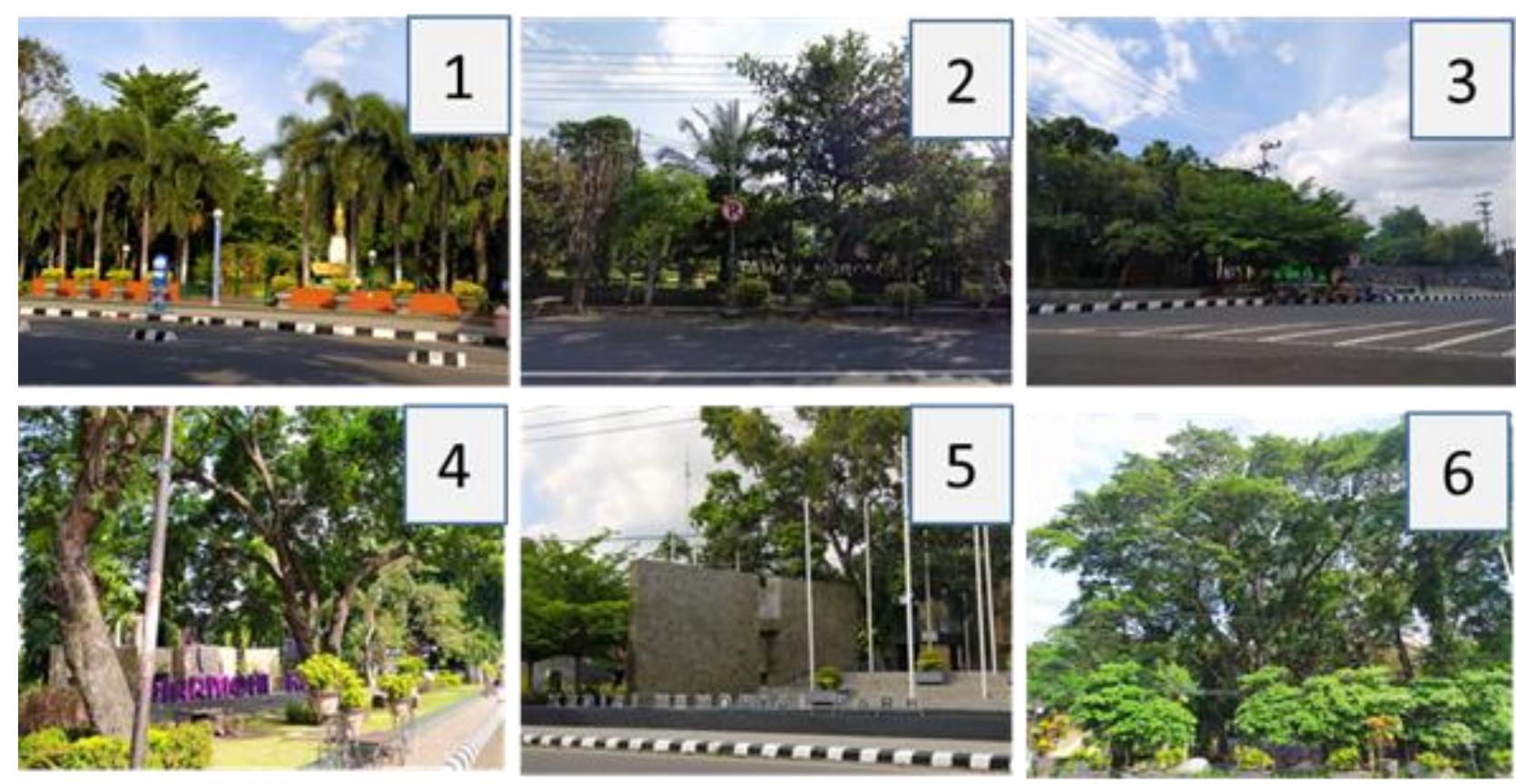

Figure 1. The study sites of urban parks and an urban forest of Kediri City, East Java, Indonesia: 1. The Kediri Square, 2. Ngronggo Park, 3. Sekartaji Park, 4. Harmoni Park, 5. Kediri Memorial Park, and 6. Joyoboyo Urban Forest 
Table 2. Status of the tree species in Urban Parks and an Urban Forest in Kediri City, East Java, Indonesia

\begin{tabular}{|c|c|c|c|c|}
\hline Local name & Scientific name & Family & Exotic or native & IUCN \\
\hline Akasia & Acacia mangium Willd. & Fabaceae & $\mathrm{E}$ & LC \\
\hline Angsana & Pterocarpus indicus Willd. & Fabaceae & $\mathrm{N}$ & EN \\
\hline Aren & Arenga pinnata (Wurmb) Merr. & Arecaceae & $\mathrm{N}$ & NA \\
\hline Beringin & Ficus benjamina $\mathrm{L}$. & Moraceae & $\mathrm{N}$ & $\mathrm{LC}$ \\
\hline Bintaro & Cerbera manghas $\mathrm{L}$. & Apocynaceae & $\mathrm{N}$ & $\mathrm{LC}$ \\
\hline Blimbing & Averrhoa carambola $\mathrm{L}$. & Oxalidaceae & $\mathrm{N}$ & NA \\
\hline Bunga kupu-kupu & Bauhinia purpurea $\mathrm{L}$. & Fabaceae & $\mathrm{E}$ & NA \\
\hline Cemara angin & Casuarina equisetifolia $\mathrm{L}$. & Casuarinaceae & $\mathrm{N}$ & $\mathrm{LC}$ \\
\hline Flamboyan & Delonix regia (Hook.) Raf. & Fabaceae & $\mathrm{E}$ & $\mathrm{LC}$ \\
\hline Glodokan tiang & Polyalthia longifolia (Sonn.) Thwaites & Annonaceae & $\mathrm{E}$ & NA \\
\hline Jambu air & Syzygium aqueum (Burm.f.) Alston & Myrtaceae & $\mathrm{N}$ & $\mathrm{LC}$ \\
\hline Kamboja merah & Plumeria rubra L. & Apocynaceae & $\mathrm{E}$ & NA \\
\hline Karet kebo & Ficus elastica Roxb. ex Hornem. & Moraceae & $\mathrm{N}$ & NA \\
\hline Kayu putih & Melaleuca leucadendra (L.) L. & Myrtaceae & $\mathrm{E}$ & NA \\
\hline Kepuh & Sterculia foetida $\mathrm{L}$. & Sterculiaceae & $\mathrm{N}$ & NA \\
\hline Ketapang kencana & Terminalia mantaly H.Perrier & Combretaceae & $\mathrm{E}$ & LC \\
\hline Kiara payung & Filicium decipiens (Wight \& Arn.) Thwaites & Sapindaceae & $\mathrm{E}$ & NA \\
\hline Mahoni & Swietenia mahagoni (L.) Jacq. & Meliaceae & $\mathrm{E}$ & NT \\
\hline Mangga & Mangifera indica $\mathrm{L}$. & Anacardiaceae & $\mathrm{E}$ & DD \\
\hline Mindi & Melia azedarach $\mathrm{L}$. & Meliaceae & $\mathrm{E}$ & $\mathrm{LC}$ \\
\hline Nyamplung & Calophyllum inophyllum $\mathrm{L}$. & Clusiaceae & $\mathrm{N}$ & $\mathrm{LC}$ \\
\hline Palem kuning & Dypsis lutescens (H.Wendl.) Beentje \& J.Dransf. & Arecaceae & $\mathrm{E}$ & NT \\
\hline Palem merah & Cyrtostachys renda Blume & Arecaceae & $\mathrm{N}$ & NA \\
\hline Palem raja & Roystonea regia (Kunth) O.F.Cook & Arecaceae & $\mathrm{E}$ & NA \\
\hline Sawo manila & Manilkara zapota (L.) P.Royen & Sapotaceae & $\mathrm{E}$ & NA \\
\hline Sirsak & Annona muricata $\mathrm{L}$. & Annonaceae & $\mathrm{E}$ & $\mathrm{LC}$ \\
\hline Talok & Muntingia calabura $\mathrm{L}$. & Muntingiaceae & $\mathrm{E}$ & NA \\
\hline Trembesi & Albizia saman (Jacq.) Merr. & Fabaceae & $\mathrm{E}$ & NA \\
\hline Waru & Hibiscus tiliaceus $\mathrm{L}$. & Malvaceae & $\mathrm{N}$ & $\mathrm{LC}$ \\
\hline
\end{tabular}

Table 3. The tree species suitability assessment in urban parks and an urban forest in Kediri City, East Java, Indonesia

\begin{tabular}{|c|c|c|c|c|c|c|c|c|c|}
\hline \multirow{2}{*}{ Scientific name } & \multirow{2}{*}{ Family } & \multicolumn{6}{|c|}{ Location } & \multirow[b]{2}{*}{ Score } & \multirow[b]{2}{*}{ Level } \\
\hline & & $\mathbf{1}$ & 2 & 3 & 4 & 5 & 6 & & \\
\hline Acacia mangium & Fabaceae & - & - & + & - & - & - & 38 & $\mathrm{M}$ \\
\hline Pterocarpus indicus & Fabaceae & + & - & - & - & - & + & 40 & $\mathrm{H}$ \\
\hline Arenga pinnata & Arecaceae & + & + & - & - & - & - & 42 & $\mathrm{H}$ \\
\hline Ficus benjamina & Moraceae & + & - & + & + & + & + & 41 & $\mathrm{H}$ \\
\hline Cerbera manghas & Apocynaceae & - & + & + & - & - & - & 40 & $\mathrm{H}$ \\
\hline Averrhoa carambola & Oxalidaceae & - & - & - & - & - & + & 36 & $\mathrm{M}$ \\
\hline Bauhinia purpurea & Fabaceae & + & + & + & - & - & + & 37 & M \\
\hline Casuarina equisetifolia & Casuarinaceae & + & + & - & - & - & - & 44 & $\mathrm{H}$ \\
\hline Delonix regia & Fabaceae & + & + & + & - & - & + & 38 & M \\
\hline Polyalthia longifolia & Annonaceae & + & + & + & + & + & - & 42 & $\mathrm{H}$ \\
\hline Syzygium aqueum & Myrtaceae & - & - & - & - & - & + & 42 & $\mathrm{H}$ \\
\hline Plumeria rubra & Apocynaceae & - & + & - & - & - & - & 39 & $\mathrm{H}$ \\
\hline Ficus elastica & Moraceae & - & + & - & - & - & - & 41 & $\mathrm{H}$ \\
\hline Melaleuca leucadendra & Myrtaceae & - & - & + & - & - & - & 42 & $\mathrm{H}$ \\
\hline Sterculia foetida & Sterculiaceae & - & - & - & - & - & + & 40 & $\mathrm{H}$ \\
\hline Terminalia mantaly & Combretaceae & + & + & + & - & + & - & 37 & $\mathrm{M}$ \\
\hline Filicium decipiens & Sapindaceae & - & - & + & - & - & - & 41 & $\mathrm{H}$ \\
\hline Swietenia mahagoni & Meliaceae & - & - & - & - & + & + & 44 & $\mathrm{H}$ \\
\hline Mangifera indica & Anacardiaceae & - & - & - & - & - & + & 37 & M \\
\hline Melia azedarach & Meliaceae & - & - & + & - & - & - & 41 & $\mathrm{H}$ \\
\hline Calophyllum inophyllum & Clusiaceae & - & - & - & - & - & + & 40 & $\mathrm{H}$ \\
\hline Dypsis lutescens & Arecaceae & - & - & - & + & - & - & 40 & $\mathrm{H}$ \\
\hline Cyrtostachys renda & Arecaceae & - & + & - & - & - & - & 40 & $\mathrm{H}$ \\
\hline Roystonea elata & Arecaceae & + & + & - & - & + & + & 39 & $\mathrm{H}$ \\
\hline Manilkara zapota & Sapotaceae & + & + & - & - & + & - & 42 & $\mathrm{H}$ \\
\hline Annona muricata & Annonaceae & - & - & - & - & - & + & 37 & M \\
\hline Muntingia calabura & Muntingiaceae & + & - & - & - & - & + & 42 & $\mathrm{H}$ \\
\hline Albizia saman & Fabaceae & - & - & + & - & - & + & 41 & $\mathrm{H}$ \\
\hline Hibiscus tiliaceus & Malvaceae & - & - & - & - & _- & + & 38 & M \\
\hline
\end{tabular}

Note: 1. The Kediri Square, 2. Ngronggo Park, 3. Sekartaji Park, 4. Harmoni Park, 5. Kediri Memorial Park, and 6. Joyoboyo Urban Forest; High (H), medium (M), and low (L); presence (+) and absent (-). Source: CABI (2021); Sulistiyowati and Yuantika (2019) 


\section{Silviculture indicators}

The urban tree species must meet the silvicultural requirements, i.e., edaphic, climatic, physiographic, and biological (Indriyanto 2006). Based on ecological conditions, the number of tree species in the study sites suitable for elevation and rainfall was 29 (Table 4). They are suitable for the altitude (63-100 asl) and annual precipitation (1,000-2,021 mm per year with the number of rainy days of 80-130 per year) of Kediri City. Many of the tree species are also tolerant to high temperatures (19 species), solar radiation (24 species), drought stress (26 species), and resistance to pests and diseases (19 species).

Regarding the edaphic conditions, 28 tree species can also grow in nutrient-poor soil. Only jambu air (Syzygium aqueum) needs fertile planting media that contains many organic materials, aeration, and drainage in loose and good soil (Sagala et al. 2017). Six species can restore soil, namely trembesi (A. saman), flamboyan (D. regia), akasia (A. mangium), cemara angin ( $C$. equisetifolia), mangga $(M$. indica), and angsana ( $P$. indicus) because they can adjust atmospheric nitrogen (Karthikeyan et al. 2013; Combalicer et al. 2014; Kumar 2016: Narendra and Pratiwi 2016).

All the tree species found in the study sites are classified as evergreen trees, 26 of which have strong stems and branches. The root of the three tree species may cause damage to the surrounding buildings (pavement and road), namely trembesi ( $A . \quad$ saman), beringin ( $F$. benjamina), and angsana ( $P$. indicus). According to Syahbudin et al. (2018a), angsana ( $P$. indicus) starts to cause damage when it has a diameter from 30 to $39 \mathrm{~cm}$ (the sidewalk) and 20 to $29 \mathrm{~cm}$ (the divider). Therefore, the tree species with potential root problems must not be planted because they can be dangerous and raise public complaints (Hasan et al. 2017a; Hasan et al. 2017b).

\section{Management indicators}

Management indicators are considered for the planting method selected for the maintenance and security of urban tree species (Indriyanto 2006). Meanwhile, according to Saebo et al. (2015), the tree species selected for GOS must function as a shade (thick and dense leaves), a windbreaker (strong and tight crowns), and can reduce environmental pollution (air, soil, and water). Furthermore, in management, comprehensive aspects must be considered regarding the caring of young plants, tree removal options, and replacement of removed trees (Vogt et al. 2017). Furthermore, trees growing under unsupportive habitat conditions can still create a better and healthier environment with suitable maintenance activities, including irrigation, fertilization, management of pests and diseases, etc.

Therefore, it is necessary to plant diverse tree species to make urban trees resistant to pests and diseases and resilient to climate variability. The diversity of urban trees is important because climate change will bring several negative impacts, such as reducing rainfall, increasing temperature, $\mathrm{CO}_{2}$, particulate matter pollutants, photochemical pressure, and extremely hot days (Bussotti et al. 2014). Thus, choosing suitable trees is crucial for the management aspect. Moreover, to prevent death and severe injury from falling trees and branches, as well as root damage, four actions should be taken: (i) regularly assessing the health and structure of trees, location, and weather, (ii) cutting root and branch, (iii) applying alternate planting between the young and the old trees, and (iv) using platform mobile-based, artificial intelligence, and internet of things (IoT) to report social and environmental problems in the smart city (Brookes 2007; Syahbudin et al. 2018).

Table 4. The characteristics of tree species based on the silvicultural indicators

\begin{tabular}{|c|c|c|c|c|c|c|c|c|c|c|c|}
\hline Scientific name & & 恶 & 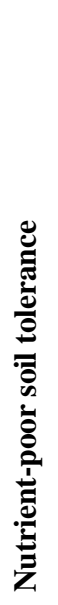 & 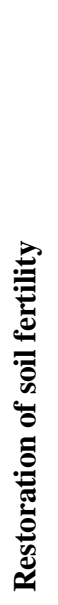 & 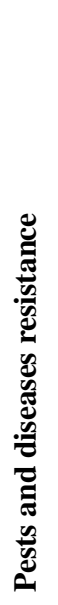 & 递 & 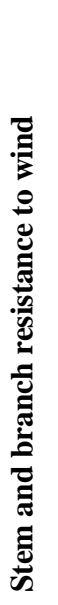 & 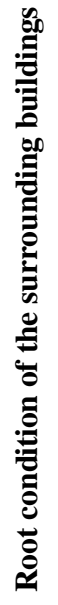 & & 芯 & 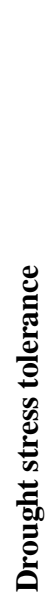 \\
\hline Acacia mangium & + & + & + & + & - & + & + & + & + & + & + \\
\hline Pterocarpus indicus & + & + & + & + & + & + & + & - & - & + & + \\
\hline Arenga pinnata & + & + & + & - & + & + & + & + & + & + & - \\
\hline Ficus benjamina & + & + & + & - & - & + & + & - & + & + & + \\
\hline Cerbera manghas & + & + & + & - & + & + & + & + & + & + & + \\
\hline Averrhoa carambola & + & + & + & - & - & + & + & + & + & + & + \\
\hline Bauhinia purpurea & + & + & + & - & + & + & + & + & + & + & + \\
\hline Casuarina equisetifolia & + & + & + & + & + & + & + & + & + & + & + \\
\hline Delonix regia & + & + & + & + & - & + & + & + & + & + & + \\
\hline Polyalthia longifolia & + & + & + & - & + & + & + & + & - & + & + \\
\hline Syzygium aquеит & + & + & - & - & - & + & + & + & - & - & - \\
\hline Plumeria rubra & + & + & + & - & - & + & + & + & + & + & + \\
\hline Ficus elastic & + & + & + & - & + & + & - & - & + & + & + \\
\hline Melaleuca leucadendra & + & + & + & - & + & + & + & + & + & + & + \\
\hline Sterculia foetida & + & + & + & - & + & + & + & + & - & - & - \\
\hline Terminalia mantaly & + & + & + & - & + & + & + & + & - & - & + \\
\hline Filicium decipiens & + & + & + & - & + & + & + & + & - & - & + \\
\hline Swietenia mahagoni & + & + & + & - & + & + & + & + & + & + & + \\
\hline Mangifera indica & + & + & + & + & - & + & + & + & + & + & + \\
\hline Melia azedarach & + & + & + & - & + & + & + & + & + & + & + \\
\hline Calophyllum inophyllum & + & + & + & - & + & + & + & + & + & + & + \\
\hline Dypsis lutescens & + & + & + & - & + & + & + & + & - & + & + \\
\hline Cyrtostachys renda & + & + & + & - & + & + & + & + & - & + & + \\
\hline Roystonea regia & + & + & + & - & + & + & + & + & - & + & + \\
\hline Manilkara zapota & + & + & + & - & - & + & + & + & + & + & + \\
\hline Annona muricata & + & + & + & - & - & + & + & + & - & - & - \\
\hline Muntingia calabura & + & + & + & - & + & + & + & + & + & + & + \\
\hline Albizia saman & + & + & + & + & + & + & - & - & + & + & + \\
\hline Hibiscus tiliaceus & + & + & + & - & - & + & - & + & + & + & - \\
\hline
\end{tabular}

Note: Suitable (+) and unsuitable (-). Source: CABI (2021) 
Table 5. The functions of tree species and architecture models in urban parks and an urban forest in Kediri City

\begin{tabular}{|c|c|c|c|c|}
\hline \multirow{2}{*}{ Scientific name } & \multicolumn{2}{|c|}{ The function of the canopy } & \multirow{2}{*}{ Architecture model } & \multirow{2}{*}{ References } \\
\hline & Shade & Windbreaker & & \\
\hline Acacia mangium & + & + & Troll & Orwa et al. (2009) \\
\hline Pterocarpus indicus & + & + & Troll & Orwa et al. (2009) \\
\hline Arenga pinnata & - & - & Corner & CABI (2021) \\
\hline Ficus benjamina & + & + & Troll & CABI (2021) \\
\hline Cerbera manghas & - & - & Koriba & CABI (2021) \\
\hline Averrhoa carambola & + & - & Troll & CABI (2021) \\
\hline Bauhinia purpurea & + & + & Troll & CABI (2021) \\
\hline Casuarina equisetifolia & + & + & Rauh & CABI (2021) \\
\hline Delonix regia & + & - & Troll & CABI (2021) \\
\hline Polyalthia longifolia & - & + & Raux & CABI $(2021)$ \\
\hline Syzygium aqueum & + & + & Troll & Sirisha and Shreeja (2019) \\
\hline Plumeria rubra & - & - & Leeuwenberg & CABI (2021) \\
\hline Ficus elastica & + & - & Troll & CABI (2021) \\
\hline Melaleuca leucadendra & - & - & Rauh & CABI (2021) \\
\hline Sterculia foetida & + & - & Aubreville & CABI (2021) \\
\hline Terminalia mantaly & + & - & Aubreville & CABI (2021) \\
\hline Filicium decipiens & - & - & Troll & CABI (2021) \\
\hline Swietenia mahagoni & + & + & Rauh & Orwa et al. (2009) \\
\hline Mangifera indica & + & - & Scarrone & CABI (2021) \\
\hline Melia azedarach & + & + & Troll & CABI (2021) \\
\hline Calophyllum inophyllum & + & + & Leeuwenberg & CABI (2021) \\
\hline Dypsis lutescens & - & - & Corner & CABI (2021) \\
\hline Cyrtostachys renda & - & - & Corner & CABI (2021) \\
\hline Roystonea regia & - & - & Corner & CABI (2021) \\
\hline Manilkara zapota & + & + & Troll & Orwa et al. (2009) \\
\hline Annona muricata & + & + & Troll & CABI (2021) \\
\hline Muntingia calabura & + & + & Troll & Ken Fern (2014) \\
\hline Albizia saman & + & - & Troll & CABI (2021) \\
\hline Hibiscus tiliaceus & + & - & Scarrone & CABI (2021) \\
\hline
\end{tabular}

Note: Suitable (+) and unsuitable (-)

Some of the tree species in the study sites can be used as a windbreaker (13 species) and a canopy shade (20 species). In addition, most architectural models of trees are a troll (14 species). On the other hand, through the urban food forest concept, which is a multidisciplinary approach between urban forestry, edible landscaping, urban agriculture, and agroforestry, woody food-producing species can also contribute to food security and natural medicine sources in a city (McLain et al. 2012; Clark and Nicholas 2013; Poe et al. 2013). Furthermore, a sustainable urban forest can restore the city and bring it closer to nature (Afrianto and Tamnge 2015).

Trees selection based on the potential for reducing air pollution in cities must be considered as one of the critical aspects. Urban tree species that can absorb (i) carbon monoxide (CO) were kiara payung ( $F$. decipiens), and bunga kupu-kupu (B. purpurea) (Kusminingrum 2008), (ii) heavy metal lead $(\mathrm{Pb})$ were mahoni $(S$. mahagoni), angsana (P. indicus), manga (M. indica), bunga kupu-kupu (B. purpurea), glodokan tiang ( $P$. longifolia), bunga kupukupu (B. purpurea), and akasia (A. mangium) (Dahlan et al. 1989; Siringoringo 2000; Yudha et al. 2013; Fahruddin $2020)$, and (iii) nitrogen dioxide (NO2) were angsana $(P$. indicus) and flamboyan (D. regia) (Sulistijorini 2009).

\section{Aesthetic indicators}

Aesthetic indicators are divided into five criteria supporting urban parks and forests (Saebo et al. 2005; Indriyanto 2006). Firstly, the urban tree species selected should have a beautiful canopy, branching, leaves, and flowers to function as an aesthetic enhancer or the beauty of an urban environment. In this present study, several ornamental plant species were found, such as trembesi (A. saman), flamboyan (D. regia), kamboja merah $(P$. rubra), palem kuning $(D$. lutescens), palem merah $(C$. renda), and palem raja ( $R$. regia).

Secondly, the urban tree species selected should have the function of education, health improvement, and social culture. Several mental health issues, such as anxiety, stress, depression, and post-traumatic stress disorder, can be reduced by watching aesthetic plants (Husti et al. 2015; Hassan et al. 2018; Hall and Knuth 2019). In Javanese culture, beringin ( $F$. benjamina) with troll architecture model has a philosophical value as the protection symbol (Syahbudin et al. 2018b). Besides serving aesthetic purposes, planting native and endangered species in GOS, such as angsana ( $P$. indicus), can conserve those species and educate the community.

Thirdly, the urban tree species selected should have relatively small fruit so that it does not endanger humans or 
damage surrounding facilities/buildings when it falls. In this study, the tree species with no large fruit may potentially cause damage to people at the sites.

Fourthly, those urban tree species must not produce sap toxic or harmful to living things. Several tree species in the study sites have been reported as poisonous species. For example, Mindi (M. azedarach) is a traditional Chinese medicine for antifungal and antiphrastic agents. But, this species has been reported to contain poison for humans that were indicated to causing in respiratory, gastrointestinal, neurological effects, cardiovascular, and death in severe cases (Phua et al. 2008). In the Eastern Province of Sri Lanka, seeds of bintaro (C. manghas) are commonly used for self-poisoning (Selladurai et al. 2016). Through IQ Ultra chambers, the stem and leaf of mangga ( $M$. indica) and waru $(H$. tiliaceus) demonstrated allergic contact dermatitis (Watts et al. 2017).

Lastly, those urban tree species must not produce pollen that is potentially allergenic to humans. Persons with latex allergy and atopic are suggested to avoid beringin $(F$. benjamina) (Axelsson 1995; Schenkelberger et al. 1998; Werfel et al. 2001). Queensland Government and the United States Department of Agriculture (USDA) classified kamboja merah (P. rubra) as a poisonous plant ("USDA" n.d.; "Queensland Government" n.d.). Blimbing (A. carambola) has clinical evidence containing high levels of oxalic acid that may cause renal failure in humans (Neto et al., 2003). Pollen allergens have been rising in the last decades because of climate change impact (Damialis et al. 2019). Pollen allergens showed a high-risk factor for asthma and seasonal allergic rhinitis (Chen et al. 2016). In this study, for instance, cemara angin ( $C$. equisetifolia) and flamboyan ( $R$. regia) had been reported as aeroallergen (Bucholtz et al. 1987; Raj and Prakshumar 2018). In addition, to prevent that, education boards must describe the poisoning that may result from these species and the risk of allergen pollen to visitors.

In conclusion, from this study, it can be concluded that the diversity of urban tree species (29 urban tree species from 17 families) is essential for urban parks and an urban forest in Kediri City, such as the conservation of germplasm, recreation, and protection. Moreover, the suitability levels of urban tree species in urban parks and an urban forest of Kediri City were medium to high (36-44). Therefore, planting suitable urban tree species will effectively mitigate the impacts of environmental problems such as climate change, pests and diseases, and management problems.

\section{ACKNOWLEDGEMENTS}

We thank Dini Ayu Lestari for her help in creating the study site map. All authors contributed equally to the experiment and the writing of this paper. Furthermore, all authors declared no conflict of interest.

\section{REFERENCES}

Afrianto WF, Tamnge F. 2015. Conceptual foundation to develop ecosmart city in Indonesia. In: Fernadez JC, Wulandari D, Damayanti EK (eds). Proceedings of SEAMEO BIOTROP Second International Conference on Tropical Biology: "Ecological Restoration in Southeast Asia: Challenges, Gains, and Future Directions". SEAMEO BIOTROP, Bogor, 12-13 October 2015. [Indonesian].

Amianti IP, Mustika SJ, Adriyanti D, Adriana, Syahbudi A. 2019. Species composition and urban forest structure in Trenggalek Regency. East Java Pros Sem Nas Masy Biodiv Indon 5 (1): 139-144. DOI: 10.13057/psnmbi/m050126.

Ardani C, Hanafi N, Pribadi T. 2013. Area prediction of green open space to complete Oxygen requirement in Palangkaraya. J. Hutan Trop. 1(1): 32-36. DOI: 10.20527/jht.v1i1.1481.

Axelsson IGK. 1995. Allergy to Ficus benjamina (weeping fig) in nonatopic subjects. Allergy 50 (3): 284-285. DOI: 10.1111/j.13989995. 1995.tb01149.x.

Brookes A. 2007. Preventing death and serious injury from falling trees and branches. J Outdoor Environ. Educ11 (2): 50-59.

Bucholtz GA, Hensel 3rd AE, Lockey RF, Serbousek D, Wunderlin RP. 1987. Australian pine (Casuarina equisetifolia) pollen as an aeroallergen. Ann Allergy 59 (1): 52-56.

Bussotti F, Pollastrini M, Killi D, Ferrini F, Fini A. 2014. Ecophysiology of urban trees in a perspective of climate change. Agrochimica 58 (3): 247-268. DOI: 10.12871/0021857201431.

CABI. 2021. Forestry Compendium. (Retrieved from https://www.cabi.org/fc/)

Chen M, Xu J, Devis D, Shi J, Ren K, Searle I, Zhang D. 2016. Origin and functional prediction of pollen allergens in plants. Plant Physiol 172 (1): 341-357. DOI: $10.1104 / p p .16 .00625$.

Clark KH, Nicholas KA. 2013. Introducing urban food forestry: a multifunctional approach to increase food security and provide ecosystem services. Landscape Ecol 28: 1649-1669. DOI: 10.1007/s10980-013-9903-z.

Combalicer MS, Lee DK, Park YD, Bae KK. 2014. The potentials of nitrogen fixing tree species for forest restoration in the Philippines. Intl Res J Biol Sci 3 (6): 73-82.

Dahlan EN, Ontaryo Y, Umasda. 1989. Lead content in leaves of wayside trees on Jalan Sudirman, Bogor. Media Konservasi 2 (4): 45-50.

Damialis A, Traidl-Hoffmann C, Treudler R. 2019. Climate Change and Pollen Allergies. In: Marselle M, Stadler J, Korn H, Irvine K, Bonn A. (eds) Biodiversity and Health in the Face of Climate Change. Springer, Cham.

e Silva JLS, de Oliveira MTP, Oliveira W, Borges LA, Cruz-Neto, O, Lopes AV. 2020. High richness of exotic trees in tropical urban green spaces: reproductive systems, fruiting and associated risks to native species. Urban For Urban Green 50: 1-10. DOI: 10.1016/j.ufug.2020.126659.

Fahruddin F. 2020. Accumulation of heavy metal lead $(\mathrm{Pb})$ and effect of stomates number on green champaca leaves (Polyaltia longifolia) in industrial area of Makassar City. Intl J Appl Biol 4 (2): 1-8.

Fitri A, Invanni I, Amal. 2020. The level of needs green open space. La Geografia 18 (2): 91-98.

Frank SD, Backe KM, McDaniel C, Green M, Widney S, Dunn RR. 2019. Exotic urban trees conserve similar natural enemy communities to native congeners but have fewer pests. PeerJ 7: 1-21. DOI: $10.7717 /$ peerj.653.

Hall C, Knuth M. 2019. An update of the literature supporting the wellbeing benefits of plants: a review of the emotional and mental health benefits of plants. J Environ Hortic 37 (1): 30-38. DOI: 10.24266/0738-2898-37.1.30.

Hasan R, Othman N, Ismail F. 2017a. Tree Species Selection in Street Planting: It's relationship with issues in urban areas. In Environment Behaviour Proceeding Journal. 6th AMER International Conference on Quality of Life. Pulau Perhentian Resort, Malaysia, 03-04 March 2018.

Hasan R, Noriah O, Faridah I. 2017b. Choosing tree for urban fabric: role of landscape architect. In Environment Behaviour Proceeding Journal. 6th AMER International Conference on Quality of Life. Pulau Perhentian Resort, Malaysia, 03-04 March 2018.

Hassan A, Qibing C, Tao J, Bing-Yang Lv, Nian L, Li S, Tng, LY, Li JZ, Ziyue SG. 2018. Effects of plant activity on mental stress in young adults. HortScience 53 (1): 104-109. DOI: 10.21273/HORTSCI12447-17. 
Hirokawa K. 2011. Sustainability and the urban forest: An ecosystem services perspective. Nat Resour J 51 (2): 233-259. DOI 10.2139/ssrn.1722650.

Husti AM, Contiu I, Radu M, Ioana N, Cantor M. 2015. Psychological benefits of ornamental plants used in office environments. Bull Univ Agric Sci Vet Med Cluj-Napoca 72 (1): 101-107. DOI: 10.15835/buasvmcn-hort:10625.

Indriyanto. 2006. Identification and suitability of vegetation species in Bandar Lampung City. Prosiding Seminar Hasil-hasil Penelitian dan Pengabdian kepada Masyarakat, Buku I. Lembaga Penelitian Universitas Lampung, Bandar Lampung. [Indonesian].

IUCN. 2021. The IUCN Red List of Threatened Species. (Retrieved from: https://www.iucnredlist.org/en)

Jasmani Z, Ravn HP, Konijnendijk CC, van den Bosch CCK. 2016 Introducing a method for social-ecological assessment of small urban parks. Environ Proc J 1 (2): 123-131. DOI: 10.21834/e-bpj.v1i2.277.

Julianty NC, Nurzaman M, Mutaqin AZ. 2015. The relationship between leaf and particulate accumulation and lead $(\mathrm{Pb})$ in the leaves of Pterocarpus indicus Willd., Swietenia macrophylla King., and Filicium decipiens (Wight \& Arn) Thwaites in the Lansia Park area of Bandung. Biotika 13 (2): 1-9. DOI: 10.24198/bjib.v13i2.10108.

Karthikeyan A, Chandrasekaran K, Geetha M, Kalaiselvi, R. 2013. Growth response of Casuarina equisetifolia Forst. rooted stem cuttings to Frankia in nursery and field conditions. J Biosci 38 (4): 741-747. DOI: 10.1007/s12038-013-9362-3.

Ken Fern. 2014. Muntingia calabura. (Retrieved from http://tropical.theferns.info/viewtropical.php?id=Muntingia+calabura)

Kumar V. 2016. Casuarina equisetifolia L.: A potential tree. Van Sangyan 3 (9): 14-17.

Kusminingrum, N. 2008. The potential of plants in absorbing $\mathrm{CO}_{2}$ and $\mathrm{CO}$ to reduce the impact of global warming. J Permukiman 3 (2): 96-105.

Narendra BH, Pratiwi P. 2016. Adaptability of some legume trees on quartz tailings of a former tin mining area in Bangka Island, Indonesia. J Degrad Min Lands Manag 4 (1): 671-674. DOI: 10.15243/jdmlm.2016.041.671

Neto MM, da Costa JAC, Garcia-Cairasco N, Netto JC, Nakagawa B, Dantas M. 2003. Intoxication by star fruit (Averrhoa carambola) in 32 uraemic patients: treatment and outcome. Nephrol Dial Transplant 18 (1): 120-125. DOI: $10.1093 / \mathrm{ndt} / 18.1 .120$.

Ningtyas T. 2019. Utilization of public green open space (RTH) in Kediri City. J Ilmu Manajemen Publik dan Kebijakan Sosial 3(1): 291-305. DOI: 10.25139/jmnegara.v3i1.1898. [Indonesian]

Núñez-Floreza R, Pérez-Gómez U, Fernández-Méndez F. 2019. Functional diversity criteria for selecting urban trees. Urban For Urban Green 38: 251-266. DOI: 10.1016/j.ufug.2019.01.005.

McLain R, Melissa P, Hurley PT, Mastenbrook JL, Emery MR. 2012. Producing edible landscapes in Seattle's urban forest. Urban For Urban Green 11: 187-194. DOI: 10.1016/j.ufug.2011.12.002.

Mukhlison. 2013. Tree species selection for urban forest development in Yogyakarta City. J Ilmu Kehutanan 7 (1): 38-47.

Orwa, Mutua A, Kindt R, Jamnadass R, Anthony S. 2009. Agroforestree Database: a tree reference and selection guide version 4.0 (Retrieved from

http://www.worldagroforestry.org/sites/treedbs/treedatabases.asp)

Paulina PD, Murtedjo. 2018. Study of the Suitability of city parks' function as green open space (multisite study in three urban parks in Kediri). Swara Bhumi 5 (2): 170-177.

Phua DH, Tsai WJ, Ger WJ, Deng JF, Yang CC. 2008. Human Melia azedarach poisoning. Clin Toxicol 46 (10): 1067-1070. DOI 10.1080/15563650802310929. DOI: 10.1007/s10745-013-9572-1.

Poe MR, McLain RJ, Emery M, Hurley PT. 2013. Urban Forest Justice and the Rights to Wild Foods, Medicines, and Materials in the City. Hum Ecol 41: 409-422.

Queensland Government. n.d. Frangipani (Plumeria species). (Retrieved from https://bit.ly/3eqwCPv)

Raj SRV and Prakshkumar R. 2018. Allergic evaluation of Roystonea regia (Kunth.) O. F. Cook. among Keralites, India. Ann Plant Sci 7 (2): 2063-2066. DOI: 10.21746/aps.2018.7.2.13.

Roeland S, Moretti M, Amorim JH, Branquinho C, Fares S, Morelli F, Ninemets U, Paoletti E, Pinbo P, Sgrigna G, Stojanovski V, Tiwary A, Sicard P, Calfapietra C. 2019. Towards an integrative approach to evaluate the environmental ecosystem services provided by urban forest. J For Res 30(6):1981-1996. DOI: 10.1007/s11676-019-00916
Roy S, Byrne J, Pickering C. 2012. A systemic quantitative review of urban tree benefits, costs, and assessment methods across cities in different climatic zones. Urban For. Urban Green 11:351-363. DOI: 10.1016/j.ufug.2012.06.006

Sæbø A, Borzan Z, Ducatillion C, Hatzistathis A, Kagerstrom T, Supuka J, Garcia-Valdecantos JL, Rego F, Slycken JV. 2005. The Selection of Plant Material for Street Trees, Park Trees and Urban Woodland. Springer, Berlin.

Sagala E, Sihombing H, Agustini F, Amanah D, Sembiring DD, Harahap DA. 2017. Analysis of consumer demand on Syzygium aqueum in North Sumatera, Indonesia. J Econ Finance 8 (5): 44-48.

Schenkelberger V, Freitag M, Altmeyer P. 1998. Ficus benjamina-the hidden allergen in the house. Hautarzt 49 (1): 2-5. DOI: $10.1007 / \mathrm{s} 001050050692$

Selladurai P, Thadsanamoorthy S, Ariaranee G. 2016. Epidemic selfpoisoning with seeds of Cerbera manghas in Eastern Sri Lanka: An analysis of admissions and outcome J Clin Toxicol 6 (2): 1-4. DOI: 10.4172/2161-0495.1000287.

Siringoringo HH. 2000. The ability of several types of urban trees to absorb lead particulates. Buletin Penelitian Hutan 622: 1-16.

Sirisha, K. S., \& Shreeja, K. (2019). Rose apple: A systematic review. The Pharma Innovation Journal 8 (7): 673-676

Sjöman H, Gunnarsson A, Pauleiy S, Bolhmer R. 2012. Selection approach of urban trees for inner-city environments: learning from nature. Arboric Urban For 38 (5): 194-204.

Sjöman H, Morgenroth J, Sjöman JD, Sæbø A, Kowarik I. 2016. Diversification of the urban forest - Can we afford to exclude exotic tree species? Urban For Urban Green. 18: 237-241. DOI: 10.1016/j.ufug.2016.06.011

Sjöman H, Hirons AD, Bassuk NL. 2018. Improving confidence in tree species selection for challenging urban sites: a role for leaf turgor loss. Urban Ecosyst 21 (6): 1171-1188. DOI: 10.1007/s11252-0180791-5.

Sulistijorini. 2009. Effectiveness and Tolerance of Greenbelt Plants to Reduce $\mathrm{NO}_{2}$ Pollutant from Transportation Activities. [Dissertation]. IPB University, Bogor. [Indonesian].

Sulistiyowati TI, Yuantika. Types of shade trees in urban park of Kediri city. J. Biologi dan Pembelajarannya 6 (1): 13-17. [Indonesian]

Syahbudin A, Syaufina RL, Yudhistira R, Sadono R. 2018a. Tree architecture models, canopy maintenance, and associated root problems of angsana (Pterocarpus indicus Willd.) in the urban trees of Yogyakarta. In IOP Conference Series: Earth and Environmental Science. IPB International Convention Center, Bogor, 21 November 2017. [Indonesian].

Syahbudin A, Meinata A, Hanindita ASH, Mulyana B. 2018b. City of philosophy: evaluation of tree philosophy and its architecture in Yogyakarta philosophical axis towards UNESCO World Heritage. In: Sukartiko A, Nuringtyas T, Marliana S, Isnansetyo A (eds). Universitas Gadjah Mada, Yogykarta, 26 - 27 Oct 2017. [Indonesian].

Turner-Skoff J, Cavender N. 2019. The benefits of trees for livable and sustainable communities. Plants, People, Planet 1: 323-335. DOI: 10.1002/ppp3.39

USDA. n.d. Poisonous Plants-Plumeria rubra. (Retrieved from https://bit.ly/3jJyaoI)

Vogt J, Gillner, S, Hofmann, M, Tharang, A, Dettmann, S, Gerstenberg, T, Schmidt C, Gebauer H, de Riet KV, Berger U, Rollof A. 2017. Citree: A database supporting tree selection for urban areas in temperate climate. Landscape and Urban Planning 157: 14-25.

Watts TJ, Li PH, Thomas I, Haque R. 2017. Occupational allergic contact dermatitis due to multiple tropical plant species. J Allergy Clin Immunol. Pract 5 (1411-2): 2213-2198. DOI: 10.1016/j.jaip.2017.04.026.

Werfel S, Ruëff F, Przybilla B. 2001. Anaphylaktische Reaktion durch Ficus benjamina (Birkenfeige) [Anaphylactic reaction to Ficus benjamina (weeping fig)]. Der Hautarzt 52 (10): 935-7. DOI: 10.1007/s001050170001.

Wiryono, Yansen, Aditya, Lamhot DJ, Hutahaean J. 2018. The species diversity and composition of roadside trees in five cities in Sumatra, Indonesia. Biodiversitas 19 (5): 1615-1621. DOI: 10.13057/biodiv/d190503

Yudha GP, Noli ZA, Idris M. 2013. The leaves grow of angsana (Pterocarpus indicus Willd) and lead $(\mathrm{Pb})$ accumulation. J Biol Univ Andalas 2 (2): 83-89. 